DOI:

Роман Михаць, кандидат педагогічних наук, стариий викладач кафедри народних музичних інструментів та вокалу Навчально-наукового інституту музичного мистеитвва Дрогобииького державного педагогічного університету імені Івана Франка

\title{
ОСОБЛИВОСТІ РОЗВИТКУ АМАТОРСЬКОГО ТЕАТРАЛЬНОГО РУХУ В СХІДНІЙ ГАЛИЧИНІ НАПРИКІНЦІ ХІХ - ПОЧАТКУ ХХ СТ.
}

У статті розглянуто особливості розвитку аматорського театрального руху Східної Галичини на межі ХІХ - ХХ століть та доведено, щзо аматорський рух спричинився до висвітлення етнонаціональних особливостей украйнського народу, його мови, рис національного характеру, світосприймання, та, найважливіше, формування національної самосвідомості особистості. Констатовано, щчо просвітницька робота, проведена професійним театральним товариством "Руська Бесіда", з часом перетворилася на нові погляди професійного театрального мистецтва Галичини, діяльність котрого спрямована на становлення та реалізацію національної особистості, ї̈ духовного потениіалу, а також гуманізацію відносин в украӥнському суспільстві загалом.

Ключові слова: театр; вистава; аматорський театральний рух; просвітницька діяльність; Товариство "Руська бесіда".

Jim. 6.

Roman Mykhats, Ph.D.(Pedagogy), Senior Lecturer of the Folk Music Instruments and Vocals Department Educational and Scientific Institute of Musical Arts Drohobych Ivan Franko State Pedagogical

\section{PECULIARITIES OF THE DEVELOPMENT OFTHE AMATEUR THEATRE MOVEMENT IN THE EASTERN GALICIAAT THE END OF 19th - BEGINNING OF THE 20th CENTURY}

The article considers the peculiarities of the development of the amateur theatre movement in Eastern Galicia at the turn of the XIX - XX centuries and it is proved that the amateur movement contributed to the coverage of ethno-national peculiarities of the Ukrainian people as well as its language, traits of national character, worldview and, most importantly, national identity. It is shown that the secular culture in Western Ukraine intensified in the middle of the 19th century, which was the time of awakening of the national and social consciousness of the Ukrainian people. It states that the educational work conducted by the professional theater society "Ruska Besida" turned into new views of professional theater art of Galicia over time, whose activity was aimed at the formation and realization of the national personality, its spiritual potential, as well as humanization of the social relations.

A distinctive phenomenon in the cultural and national life of Ukrainian Galicians in the early twentieth century was the creation of the Hutsul National Theatre. Theatrical activity of amateur dramatists became a driving factor in the national and cultural education of the local population in the late 19th-early 20th centuries. Amateur groups were organized under the auspices of the Ruska Besida Society, which were distributed in cities and towns of Eastern Galicia. They produced plays by both Ukrainian-language authors (I. Kotlyarevskiy, H. Tsehlinskiy) and foreign (M. Gorky, Moliere). The main function of amateur groups was to educate the broad sections of Ukrainians in the region, their national upbringing by means of theatrical art through the formation of linguistic culture, respect for national customs and traditions.

The most extensive cultural and educational network in Eastern Galicia was Prosvita Society, which had branches and reading rooms in the most remote corners of the region. The activities of the amateur circles in the Prosvita centers focused mainly on the production of plays by Ukrainian authors - those were dramatic works, comedies and vaudevilles. In the history of Ukrainian theater amateur theatre troupes and playgroups played an important role, as they spread Ukrainian culture, conducted educational activities, contributed to raising the national consciousness of the Ukrainian people. The theater became a real stronghold of folk revival, pure folk language sounded from its stage; the plays themselves attracted audiences by colorful, bright national music raising educational awareness.

Keywords: theatre; performance; amateur theatre movement; educational activity; "Ruska Besida".

П

оостановка проблеми. В сьогоденні українська культура й освіта $\epsilon$ органічною єдністю у формуванні громадянського суспільства 3 високим рівнем духовної, соціальної, освітньої, політичної, економічної культури, і саме початок інтенсивного 


\section{ОСОБЛИВОСТІ РОЗВИТКУ АМАТОРСЬКОГО ТЕАТРАЛЬНОГО РУХУ В СХІДНІЙ ГАЛИЧИНІ НАПРИКІНЦ ХІХ-ПОЧАТКУ ХХ СТ.}

розвитку світської культури в Західній Україні припадає на середину XIX ст. - епоху пробудження національної і соціальної свідомості українського народу. Важливість дослідження особливостей розвитку українського аматорського театрального руху крізь призму формування національної тотожності молодого покоління зазначеного періоду зумовлюється пошуком альтернативних моделей організації освіти, створення цілісної системи національного виховання, сприяння культурному, моральному й духовному розвитку. Український театр з часу існування виконував виконує дуже важливе національно-патріотичне завдання, що дає нам підставу вести мову про освітні, просвітницькі тенденції театрального мистецтва: “український народ мав у ньому дуже сильну, часами єдину зброю в змаганні за свої права на полі мови, звичаїв, взагалі своєї власної культури..." [5, 337].Серед важливих здобутків українців Східної Галичини в середині ХІХ століття було скасування панщини, створення Головної Руської Ради - першої легальної політичної організації, що боролася за національні права українців в Австрійській імперії, участь українського населення у виборах до парламенту, створення національної гвардії (батальйонів руських гірських стрільців), впровадження у народних школах навчання українською мовою, уведення вивчення української мови в гімназіях Галичини. На цей час припадає також створення культурно-освітньої організації - "ГалицькоРуська Матиця”, що займалася просвітницькою діяльністю й друкуванням та поширенням українських дешевих книг серед населення краю, поява перших українських аматорських гуртків й театрів. Як видно, “Весна народів” у Східній Галичині проявилася найбільше у національнокультурному піднесенні українців, у якому ключову роль для самоідентифікації народу відіграла рідна мова. Пропагандою рідної мови займалися як представники політичних і громадських організацій, так і школи, просвітницькі товариства, театри, драматичні гуртки.

Аматорський театральний рух Східної Галичини другої половини XIX - початку XX ст. спричинився до висвітлення етнонаціональних особливостей українського народу, його мови, рис національного характеру, світосприймання, та, найважливіше, формування національної самосвідомості особистості, що є не тільки національною ідентифікацією, а й включає складніший компонент творення нації- уявлення про культуру, історичне минуле свого народу та $є$ проекцією у майбутнє.

Аналіз останніх досліджень і публікацій.
До проблеми вивчення історії розвитку аматорського українського театру, його виховного впливу зверталися культурологи, мистецтвознавці, літературознавці, історики, педагоги як довоєнної, радянської доби, так і сучасності. Серед дослідників українського театру, зокрема і в Галичині, слід назвати Д. Антоновича, Б. Грінченка, М. Грушевського, К. Новак-Вольну, С. Пепловського, Р. Пилипчука, О. Рудницьку, I. Стешенката ін. У їхніх працях головна увага зосереджувалася на становленні й розвитку аматорського і професійного театру в Україні на різних історичних етапах, його просвітницькій та націєтворчій ролі.

Мета статті - визначення особливостей розвитку аматорського театрального руху в Східній Галичині наприкінці XIX - початку XX ст.

Виклад основного матеріалу.Аналізуючи особливості розвитку аматорського театру, варто зазначити, що історія розвитку аматорського театру Східної Галичини середини XIX ст. почалася 3 I. Озаркевича, греко-католицького священика, драматурга, педагога й громадського діяча. У травні 1848 р. в Коломиї о. І. Озаркевич 3 акторами-аматорами здійснює постановку вистави “Наталка-Полтавка" І. Котляревського, адаптувавши іiі до західного регіону України під назвою “Дівка на виданні, або На милування нема силування”. Автор наділив головну героїню іменем Аничка, а Виборний у нього став Десятським. Музичний матеріал базувався також на місцевому мелосі. Так, відома пісня Наталки “Видно шляхи Полтавські і славну Полтаву, пошануйте сиротину і не вводьте в славу”, була адаптована до відповідного регіону “Видно шляхи Коломийські, славну околицю, пошануйте сиротину, бідную дівицю" $[4,25]$. Тут автор виступає прихильником просвітницьких тенденцій української культури, започатковує просвітницьку міщанську драму. Слід зазначити, що завдяки просвітницькій діяльності І. Котляревського зароджується новий тип українського театру: на сцені з'являється українська людина - втілення в художньому образі українського національного характеру. Загальне добро для героїв I. Котляревського $є$ морально-етичною нормою співжиття усіх громадян, незалежно від їх соціального статусу. Доброчесність, шанобливе ставлення до батьків, плекання сімейних традицій, родових звичаїв, моральних християнських цінностей і патріархальних норм життя, вірність у коханні, безкорисливість, щирість, милосердя - це та система національних цінностей, яку утверджує і поетизує автор “Наталки Полтавки”. "Він також розкриває відмінність двох національно- 


\section{ОСОБЛИВОСТІ РОЗВИТКУ АМАТОРСЬКОГО ТЕАТРАЛЬНОГО РУХУ}

В СХІДНІЙ ГАЛИЧИНІ НАПРИКІНЦІ ХІХ-ПОЧАТКУ ХХ СТ.

культурних типів - українця і росіянина (малороса і москаля)" [2, 233]. Цілком очевидно, що успіх перших українських вистав сприяв появі аматорських гуртків і театрів. У 1848 р. утворилися українські аматорські театральні трупи в Коломиї, Львові та Перемишлі. У їх формуванні активну участь взяли о. І. Озаркевич (Коломия) та о. М. Вербицький (Перемишль).

Перші вистави у Львові відбулися 1848 року за участю вихованців духовної семінарії, і ця ж аматорська театральна трупа ставила п’єсу I. Котляревського "Наталка-Полтавка", а також п’єсу “В вівторок по Михайлі”, що мала значний успіх серед львів'ян. Слід відзначити, що репертуар театруготувалипедагоги перемишльських гімназій (Ю. Желеховський, М. Полянський, I. Айталевич), а музику до них писав відомий український композитор Михайло Вербицький. На сцені Народного дому Перемишля цей аматорський театр ставив такі п’єси: “Наталка Полтавка", “Старий візник Петра III”, “Козак і охотник”, “Проциха”, “Верховинці” та ін. Компонуючи музику до цих вистав, М. Вербицький часто звертався до фольклору, пристосовував коломийкові, шумкові інтонації та ритми як у вокальній, так і в інструментальній музиці. Фольклорні мотиви композитор “черпав" iз уст краян, а також із збірника В. Залеського відомого збирача і видавця народних пісень. Саме завдяки цьому, театральна музика Вербицького має чисто народний характер і користувалася успіхом.

3 огляду на тему нашого дослідження, ключову роль у формуванні національної ідентичності українців Східної Галичини відіграло створення Народного Дому у Львові, а згодом і в інших містах краю. Так, перший Народний дім постав у Львові (1851-1864). Пропозицію щодо його створення було оголошено ще у червні 1848 р. Л. Трещаківським на засіданні Головної Руської Ради. Основним завданням Дому було піднесення духовної культури українців Східної Галичини через організацію національно-культурних товариств, театрів, народних шкіл, проведення різноманітних культурно-просвітницьких заходів, патріотичних акцій та ін. При Народному Домі у Львові діяла перша українська академічна гімназія (1862), велика бібліотека, очолювана істориком й лінгвістом А. Петрушевичем, функціонували археологічний та природничий музеї, в актовій залі здійснювалися постановки Народного Руського Театру, а також вели свою діяльність низка культурно-освітніх товариств, зокрема й товариство Галицько-Руської Матиці. Для заснування справжнього українського театру було чимало причин: відсутність свого приміщення (сцени, театральної зали), постановочного матеріалу (оригінальних авторських п’єс), i, врешті-решт виконавського апарату (акторів, режисерів, музикантів).

Великим прихильником театральної справи був письменник, драматург Г. Якимович, який пропонував на початку 1862 р. показати у Львові декілька аматорських вистав, 3 якими можна було б виступити у провінційних містах Галичини. Однак Ю. Лавровський, очевидно, мав свій план щодо заснування українського театру. Здавалося б, можна приступати й до організації театру, якби було завершене будівництво народного дому, однак робота в цьому напрямі не сповільнювалася. У грудні цього ж року було створено "Виділ для ведення первоначальних діл руського театру”, до якого ввійшли I. Товарницький (голова), С. Згарський (народовець), К. Мерунович (москвофіл) - обидва в майбутньому драматурги, a також юрист I. Сиротюк та технік Гавришкевич. Протягом 1863 р. Відділом Руської Бесіди проводилась копітка просвітницько-освітня робота а саме: засновано руську драматичну школу, завершувалися оздоблювальні роботи у майбутній театральній залі народного дому, почали проводитися декламаторські вечори, концерти, вилучені кошти від яких збиралися для майбутнього театру.

На початку 1864 р. Ю. Лавровський від імені Товариства "Руська Бесіда" звертається до президії Галицького Намісництва у Львові про надання дозволу на відкриття постійного українського професійного театру у Львові, одночасно веде перемовини із О. Бачинським на предмет керівника майбутнього театру. 4 березня цього ж року цісарський намісник в Галичині граф А. Менсдорф все ж таки надає дозвіл на відкриття театру, про що повідомляла Львівська та Віденська преса. Просвітницька діяльність національно-свідомої інтелігенції в Галичині сприймалася як протест проти репресивних заходів російського уряду щодо української культури в межах Російської імперії. Заснування українського театру у Львові в межах Австрійської монархії, на тлі антиукраїнської політики російського царизму виглядало доброчинством Австрійського уряду, “відсутність державності в повному розумінні цього поняття обмежувала можливість трансляції духовнокультурних цінностей, зумовлювала пріоритет збереження і культивування традиційної культури як гаранта збереження етнічної ідентичності й викликала спротив намаганню динамічно модернізувати традиційні напрями, стилі, форми" 


\section{ОСОБЛИВОСТІ РОЗВИТКУ АМАТОРСЬКОГО ТЕАТРАЛЬНОГО РУХУ}

В СХІДНІЙ ГАЛИЧИНІ НАПРИКІНЦІ ХІХ-ПОЧАТКУ ХХ СТ.

[2, 241]. Цей театр успішно працював до першої Світової війни.

3 ім'ям театру “Руська Бесіда” у галичан пов'язане почуття таланту, високого професіоналізму, драматизму боротьби, постійного пошуку, і таким він залишився в народній пам'яті. Констатуємо, що просвітницька робота, проведена професійним театральним товариством “Руська Бесіда”, 3 часом перетворилася на нові погляди професійного театрального мистецтва Галичини, діяльність котрого спрямована на становлення та реалізацію національної особистості, ії духовного потенціалу, а також гуманізацію відносин в українському суспільстві загалом.

Таким чином, український просвітницький театр Товариства "Руська Бесіда" від витоків свого існування 31864 р. веде просвітницькоосвітню діяльність, адже відкриваються школи та впливає на становлення і поширення театрального руху. Зауважимо, що театр Товариства "Руська Бесіда", який у різних модифікаціях успішно проіснував до 1939 р., вважається першим професійним театром у Західній Україні. Характерною рисою українського театру в цей період було долучення до драматичної дії народних обрядів, обрядових пісень, різноманітної народної лірики, а також народної хореографіі” [ 3 , 70 - 71]. Загалом, театральне товариство як осередок, утверджує на теренах Західної України національну ідею, відроджує традиції, в змісті і формах діяльності виконує просвітницьку функцію.

У 80-х pp. ХІХ ст. у Дрогобичі досить часто 3 гостинними виступами побував театр Руської бесіди. До душі для дрогобичан була п'єса "Підгіряни" о. І. Гушалевича із музикою о. М. Вербицького. Відомо, що “друга половина XIX ст. - доба становлення класичної української музики і театру. В цей час творять свої шедеври С. Гулак-Артемовський і М. Лисенко. Оригінальну музику пише М. Аркас, автор опери "Катерина" (за мотивами Т. Шевченка). Саме такою професійною трупою гастролював у 1864 р. О. Бачинський Стрийщиною, Дрогобиччиною, Самбірщиною. У наступному році ця тупа гастролювала впродовж двох місяців у Перемишлі, а також відвідала Тернопіль, Коломию, Станіслав, Бережани. Поміж найбільш популярних п'єс, що були поставлені на сцені Руського театру, слід назвати такі: “НаталкаПолтавка” І. Котляревського, “Сватання на Гончарівці" та "Москаль-чарівник” Г. КвіткиОснов'яненка, “Назар Стодоля” Т. Шевченка, “Один порадував, другий потішив” А. Ващенка-
Захарченка, "Кум-мірошник” В. Дмитренка, “Опікунство”Р. Моха, “Верховинці”’Ю. Коженьовського у перекладі К. Климковича; оперети "Бувальщина" А. Вельсовського та "Покійник Опанас" А. Янковського. 3 наведених вище назв вистав та їх авторів стає цілком зрозуміло, що діяльність Руського народного театру мала яскраво виражене національне підгрунтя. У його статі також було зазначено, що мовою театру є українська, листування дирекції, оголошення й афіші теж друкуються українською мовою.

Отож, відкриття українського театру “Руська Бесіда” стало одним із виявів боротьби українців Галичини за свою самобутню культуру, адже Галичина, яка протягом століть була складовою інших держав (Польщі, Австрії), мріяли про свою державу, про спілкування рідною мовою, про збереження і розвиток самобутньої національної культури, однак ці мрії, через відсутність власної держави, були нездійсненними протягом віків. За їхньою ініціативою було оголошено конкурс на написання кращих п'єс українською мовою, що будуть поставлені на сцені Руського народного театру. Серед таких галицьких авторів, чиї п'єси здобули прихильність театрального комітету, назвемо Й. Гушалевича (народні мелодрами: "Підгіряни” й “Сільські пленіпотенти" (пленіпотенти - уповноважений у майнових справах - прим. М.Р.), П. Свєнціцького, який писав і брав участь у виставах як актор під різними псевдонімами, як-то Лозовий, Стахурський, Павло Свій, О. Левицького, який здійснював переклади п'єс з німецької, польської та французької мов. Як видно, діяльність Руського народного театру була також спрямована на підтримку тогочасної української талановитої молоді, твори яких утверджували українську мову й культуру, сприяли піднесенню національної свідомості галичан.

Самобутнім явищем в культурно-національному житті українських галичан початку ХХ ст. було створення Гуцульського народного театру. Його засновником був Г. Хоткевич, східноукраїнський письменник, мистецтвознавець, театральний діяч, який 1906 року емігрував з Харкова до Східної Галичини, щоб уникнути ув'язнення за національно-політичну діяльність. На запрошення В. Гнатюка він відвідав Криворівню, що на Верховинщині. Г. Хоткевич захопився природою та народними говірками і вирішив залишитися тут. У 1910 р. у селі Красноїлля він заснував театр, в якому брали участь місцеві жителі аматори-актори $[1,12]$. Місцевий колорит, звичаї та обряди Г. Хоткевич відобразив у першій своїй постановці “Верховинці”. Успіх Гуцульського 


\section{ОСОБЛИВОСТІ РОЗВИТКУ АМАТОРСЬКОГО ТЕАТРАЛЬНОГО РУХУ В СХІДНІЙ ГАЛИЧИНІ НАПРИКІНЦІ ХІХ-ПОЧАТКУ ХХ СТ.}

театру був надзвичайний і сприяв його гастрольній подорожі Галичиною, яка відбулася через два роки від заснування. Найбільш репрезентативними театральними п'єсам цього театру були: “Верховинці”, “Довбуш”, “Гуцульський рік”, “Непросте”. В усіх них яскраво подано гуцульські звичаї, обряди, вірування, відображено національно-культурні й міфологічні уявлення гуцулів, актуалізовано головні тогочасні проблеми - боротьбу за соціальне й національне визволення місцевого населення. Ці вистави репрезентували також культурні особливості гуцульського народу, їхні погляди на давні вірування й обряди. Саме мовна автентичність, звернення до фольклору, патріотизм були ключовими факторами успіху цього провінційного аматорського театру.

Варто зауважити, що театральний рух у Східній Галичині досліджуваного періоду був представлений не тільки роботою перших аматорських театрів у Коломиї, Перемишлі, Львові та діяльністю Руського й Гуцульського народних театрів, що поступово набирали обрисів професійних, але й організацією театральних й драматичних гуртків, які були організовані майже при кожній культурно-просвітницькій організації.

Саме театральна діяльність аматорських драмгуртків стала рушійним чинником у національно-культурній просвіті місцевого населення кінця XIX - початку XX ст., у період, коли Руський народний театр переживав внутрішні міжусобні суперечки між представниками театрального комітету, а також почалася закулісна боротьба між керівником театру (О. Бачинським) й театральною трупою. Діяльність театру “Руської бесіди" не могла охопити усі куточки Східної Галичини і тому місцеві аматорські театральні гуртки, поряд з церквою та культурно-освітніми товариствами, були практично єдиним джерелом пропаганди української літератури й культури, виразником національної самоідентифікації широких верств українського народу в цьому регіоні.

Коротко охарактеризуємо діяльність аматорських театральних гуртків, що діяли у Східній Галичині у другій половині XIX - на початку XX ст. Так, аматорські гуртки були організовані при філіях Товариства "Руська Бесіда", що були розповсюджені у містах і містечках Східної Галичини. Вони ставили п'єси як україномовних авторів (І. Котляревського, Г. Цеглинського), так і зарубіжних (М. Горького, Мольєра). Проте їх головна функція полягала у просвітництві широких верств українців краю, їх національному вихованні засобами театрального мистецтва через формування мовної культури, поваги до національних звичаїв і традицій.
Найбільш розгалуженою культурнопросвітницькою мережею у Східній Галичині було Товариство "Просвіта", яке мало свої філії та читальні у найвіддаленіших куточках краю. У цьому контексті наголосимо, що товариство “Просвіта" було організоване у Львові 1868 р. задля захисту національно-культурного життя українців. Діяльність аматорських гуртків в осередках "Просвіти” зосереджувалася переважно на постановці п’єс українських авторів. Це були і драматичні твори, і комедії, і водевілі. Утім, незважаючи на дещо побутовий характер цих постановок, вони мали глибоко моральну і патріотичну спрямованість. Наприклад, аматорський театральний гурток в с. Денисові Тернопільського повіту, що, до речі, був одним 3 перших сільських аматорських колективів, показав першу виставу М. Кропивницького “За сиротою і Бог 3 калитою”. У ній брали участь старше покоління села.

Як бачимо, в історії українського театру аматорські театральні трупи й драмгуртки відіграли неабияку роль, оскільки поширювали українську культуру, вели просвітницьку діяльність, сприяли піднесенню національної свідомості українського народу. Театр став справжньою твердинею народного відродження, 3 його сцени лунала чиста народна мова, спектаклі приваблювали колоритною, яскраво-національною музикою, виховною спрямованістю.

Висновки. Театр як форма зовнішнього вияву мистецьких здібностей народу, в якій різні галузі мистецтва та музики об'єднуються для викликання спільного ефекту, виявляє в Україні за час свого існування характерні риси, що забезпечують йому окреме місце в межах національної та зарубіжної культури. Мистецтво театру в Україні, як і зарубіжне, завжди було синтетичним, тобто не реалізується одноосібно, а складається із різних галузей. Театр як вид мистецтва виступає своєрідною формою соціальної свідомості, засобом ідейного та естетичного виховання особистості. Складний і водночас цікавий процес еволюції аматорського й професійного театру Західної України відбувався протягом декількох століть, у другій половині XIX ст. українське професійне театральне мистецтво опинилося у скрутному становищі: був відсутній високохудожній репертуар, ще не були сформовані належні традиції режисури й акторської гри, не було спеціальних закладів, приміщень.

\section{ЛІТЕРАТУРА}

1. Арсенич П. Гуцульщина у творчості ГнатаХоткевича. До 90-річчя від дня створення 
Г.Хоткевичем самодіяльного Гуцульського театру. Івано-Франківськ, 2000.96 с.

2. Жулинський М. Г. Нація. Культура. Література: нац.-культ. міфи та ідейно-естет. пошуки укр літератури. Київ, 2010.560 с.

3. Ігошкіна Н. Г. Культурологія мистецтва : навч. посіб. Київ, 2005. 208 с

4. Коломієць Р. Феномен Коломийського театру. Практика неймовірностей. Івано-Франківськ, 2010. 143 с.

5. Мірчук І. Історія української культури. Мюнхен Львів, 1994. 373 с.

6. Нариси з історії Дрогобича (від найдавніших часів до початку XXI століття). Науковий редактор Л. Тимошенко. Дрогобич, 2009. 319 с.

\section{REFERENCES}

1. Arsenych, P. (2000). Hutsulshchyna u tvorchosti Hnata Khotkevycha. Do 90-richchia vid dnia stvorennia H.Khotkevychem samodiialnoho Hutsulskoho teatru [Hutsul region in the work of Hnat Khotkevich. To the 90th Anniversary of the Creation of the Amateur Hutsul
Theater by G. Khotkevich]. Ivano-Frankivsk, 96 p. [in Ukrainian].

2. Zhulynskyi, M. H. (2010). Natsiia. Kultura. Literatura: nats.-kult. mify ta ideino-estet. poshuky ukr. literatury [Nation. Culture. Literature: national-cult. myths and ideological aesthetics. search ukr. Literature]. Kyiv, 560 p. [in Ukrainian].

3. Ihoshkina, N. H. (2005). Kulturolohiia mystetstva : navch. posib.[Art Cultural Studies: Educ. Tool]. Kyiv, 208 p. [in Ukrainian].

4. Kolomiiets, R. (2010). Fenomen Kolomyiskoho teatru. Praktyka neimovirnostei [The phenomenon of the Kolomyia Theater. The practice of infidelity]. IvanoFrankivsk, 143 p. [in Ukrainian]

5. Mirchuk, I. (1994). Istoriia ukrainskoi kultury [History of Ukrainian Culture]. Lviv, 373 p. [in Ukrainian].

6. Narysy z istorii Drohobycha (vid naidavnishykh chasiv do pochatku XXI stolittia) (2009). [Essays on the History of Drohobych (from the Ancient Times to the Beginning of the 21 st Century)]. Scientific Editor L. Tymoshenko. Drohobych, 319 p. [in Ukrainian].

Стаття надійшла до редакції 12.07.2019

УДК 78.071.2(44=161.2)

DOI:

Оксана Бобечко, кандидат мистеитвознавства, доиент кафедри народних музичних інструментів та вокалу Дрогобицького державного педагогічного університету імені Івана Франка Наталя Тепла, студентка магістратури Інституту музичного мистеитва Дрогобицького державного педагогічного університету імені Івана Франка

\section{МИРОСЛАВ СКАЛА-СТАРИЦЬКИЙ: ШТРИХИ ДО ТВОРЧОГО ПОРТРЕТА} (до 110-річчя від дня народження видатного співака)

У статті розглядається мистеиький доробок видатного співака Мирослава Скали-Старицького (1909 - 1969), який сприяв популяризачії украӥнської музичної культури в Свропі та Америчі та став яскравим репрезентантом України у світовому полікультурному просторі. Висвітлюються його творчо-виконавська, педагогічна й громадська діяльності в контексті розвитку украӥнського та європейського вокального виконавства, аналізується внесок мития в консолідацію українців за межами рідної землі.

Ключові слова: Мирослав Скала-Старицький; вокальне мистецтво; співак; тенор; оперний театр; музично-драматична студія; еміграчія.

Jim. 6.

Oksana Bobechko, Ph.D.(Art Studies), Associate Professor of the Folk Musical Instruments and Vocal Department Drohobych Ivan Franko State Pedagogical University Nataliya Tepla, Master Student at the Institute of Musical Art Drohobych Ivan Franko State Pedagogical University

\section{MYROSLAV SKALA-STARYTSKIY: STROKES TO THE CREATIVE PORTRAIT (in honor of 110th anniversary of the great singer's birthday)}

The article deals with the artistic works of the prominent singer Myroslav Skala-Starytskiy (1909 - 1969), who contributed to the popularization of Ukrainian musical culture in Europe and America and became a vivid representative of Ukraine in the world's multicultural space. His creative, performing, pedagogical and social activities are covered in the context of the development of Ukrainian and European vocal performance art, and the artist's contribution to the consolidation of Ukrainians outside of his homeland is analyzed. The initial stage of the creative development of M. Skala-Starytskiy is examined, the stage associated with Ukraine, the period of the establishment and triumph of an outstanding singer on the concert and opera stages of Europe, America and Africa. The repertoire of the artist's work and the geography of his concert-performing activity, which impresses with its 